\title{
ADH4 wt Allele
}

National Cancer Institute

\section{Source}

National Cancer Institute. ADH4 wt Allele. NCI Thesaurus. Code C111831.

Human ADH 4 wild-type allele is located in the vicinity of $4 \mathrm{q} 22$ and is approximately $34 \mathrm{~kb}$

in length. This allele, which encodes alcohol dehydrogenase 4 protein, is involved in the metabolism of alcohols. 